\title{
Antibiotics Used for Upper Respiratory Tract Infection: a Case Study at the Primary Health Center Bogor Indonesia
}

\author{
Wiwi Ambarwati, ${ }^{1}$ Vivi Setiawaty, ${ }^{2}$ Adik Wibowo ${ }^{1}$ \\ ${ }^{1}$ Department of Health Policy and Administration, Faculty of Public Health, Universitas Indonesia, \\ Depok, Indonesia, ${ }^{2}$ National Institute of Health Research and Development, \\ Ministry of Health Republic of Indonesia, Central Jakarta, Indonesia
}

\begin{abstract}
Acute upper respiratory tract infection (URTI) is one of the health problem in a community with high prevalence and healthcare cost. At the primary health center (PHC), URTI is one of the most common diseases with a prevalence 45.64\% in Bogor city on 2015, while Basic Health Research 2013 data showed the prevalence of URTI in Indonesia by $25 \%$. This study analyzes the antibiotic prescription for URTI patients, factors influencing the rationale of antibiotic prescriptions, and the rational use of medicine (RUM) program management at Primary Health Centers at Bogor city. The research was analytic descriptive cross-sectional study by collecting data from medical records of patients diagnosed with non-pneumonia URTI, observation for outpatient health care, and interview with all responsible persons. The data were collected on 16 April-20 May 2018 from primary health centers at Bogor city. The samples were 359 oral antibiotic prescriptions of three physicians and antibiotics were prescribed for 122 (34\%) cases from 359 cases of which 102 were evaluated for rationality according to local guidelines issued by the Ministry of Health Republic of Indonesia. The URTI diagnosis is classified into few categories with the prevalence of nasopharyngitis (62.9\%), pharyngitis (30.6\%), tonsillitis (5.3\%), and sinusitis and acute otitis media (o.6\%). Most antibiotics used were amoxicillin and cefadroxil. This study revealed that antibiotics prescribed $88 \%$ inaccuracy of antibiotics duration, $12 \%$ incompatibility with the guidance of antibiotic, $3 \%$ incompatibility with guidance and imprecise duration, and $1 \%$ inaccuracy of dose. Some factors that influencing rationality of antibiotics prescription was lack of physician's adherence to the clinical guideline, pharmacist role was not optimal, and lack of monitoring evaluating.
\end{abstract}

Key words: Antibiotics, acute upper respiratory tract infections, rational use of medicine

\section{Penggunaan Antibiotik untuk Infeksi Saluran Pernapasan Atas: Studi Kasus di Pusat Kesehatan Primer Bogor Indonesia}

\begin{abstract}
Abstrak
Infeksi saluran pernapasan atas (ISPA) akut adalah salah satu masalah kesehatan dengan prevalensi dan biaya perawatan kesehatan yang tinggi. Di pusat kesehatan masyarakat (puskesmas), ISPA adalah salah satu penyakit yang paling umum dengan prevalensi 45,64\% di Kota Bogor pada tahun 2015, sementara data Riset Kesehatan Dasar 2013 menunjukkan prevalensi ISPA di Indonesia sebesar 25\%. Penelitian ini menganalisis resep antibiotik untuk pasien ISPA, faktor yang memengaruhi dasar pemberian antibiotik, dan penggunaan manajemen program pengobatan rasional di puskesmas di Kota Bogor. Penelitian ini adalah penelitian deskriptif analitik cross-sectional dengan mengumpulkan data rekam medis pasien yang didiagnosis nonpneumonia ISPA, observasi perawatan kesehatan rawat jalan, dan wawancara. Data dikumpulkan pada 16 April-20 May 2018 dari puskesmas di Kota Bogor. Sampel adalah 359 resep antibiotik oral dari tiga dokter dan antibiotik diresepkan untuk 122 (34\%) kasus dari 359 kasus yang 102 di antaranya dievaluasi untuk rasionalitas sesuai dengan pedoman yang dikeluarkan oleh Kementerian Kesehatan Republik Indonesia. Beberapa penyakit yang termasuk ISPA menunjukkan prevalensi nasofaringitis $(62,9 \%)$, faringitis $(30,6 \%)$, tonsilitis $(5,3 \%)$, serta sinusitis dan otitis media akut (o,6\%). Mayoritas antibiotik yang digunakan adalah amoksisilin dan sefadroksil. Penelitian ini mengungkapkan bahwa antibiotik yang diresepkan $88 \%$ tidak tepat durasi, 12\% tidak cocok dengan panduan, 3\% tidak cocok dengan panduan dan tidak tepat durasi, serta $1 \%$ tidak tepat dosis. Simpulan, faktor yang memengaruhi rasionalitas resep antibiotik adalah kurangnya kepatuhan dokter terhadap pedoman klinis, peran apoteker tidak optimal, dan pemantauan evaluasi yang kurang.
\end{abstract}

Kata kunci: Antibiotik, infeksi saluran pernapasan atas akut, penggunaan obat rasional

Received: 22 March 2018; Revised: 25 October 2018; Accepted: 28 November 2018; Published: 31 December 2018

Correspondence: Dr. Vivi Setiawaty, dr., M.Biomed. National Institute of Health Research and Development, Ministry of Health Republic of Indonesia. Jln. Percetakan Negara No. 29, Central Jakarta 10560, Special Capital Region of Jakarta, Indonesia. Mobile: +628179804571. E-mail: vivisetiawaty@hotmail.com 


\section{Introduction}

Antibiotics use in developing countries is very high due to infectious diseases still the main health problems. Antibiotic resistance occurs when antibiotics are no longer able to inhibit or kill bacteria that cause infection because resistant to antibiotics. ${ }^{1-3}$

The national prevalence of non-pneumonia upper respiratory tract infection in Indonesia in 2013 was $25.0 \%$. This figure is not much different from 2007 results was 25.5\%. ${ }^{4}$ Acute upper respiratory tract infection (URTI) is the most common diseases in the community, most of URTI have mild symptoms like cold, coughs caused by viruses and it doesn't need antibiotics treatment. In practice, many antibiotics are prescribed to treat this infection. Administration of antibiotics in patients that were not accompanied by adherence to drug consumption rules will increase the risk of side effects of drugs and antibiotics resistance. ${ }^{5}$ The scope on URTI in this study refers to ICD-10 version: 2016 defined by World Health Organization (WHO) as an acute upper respiratory infection. ${ }^{6}$

The rational use of drugs is associated with several factors, including health care workers, patients, patient load and health care facilities. ${ }^{7-10}$ Factors associated with increased drug prescription rationally by health workers include knowledge, training for rational drugs, and dissemination information of rational use of medicine. ${ }^{7,8}$ The rational prescription of drugs is also associated with the characteristics of health care facilities, including the availability of treatment guidelines and the availability of drugs, policy, program management, monitoring and evaluation of implementation for rational use of medicine. ${ }^{8-10}$

The report of the Directorate General of Pharmaceutical and Medical Devices, the Ministry of Health of the Republic of Indonesia in 2016 on monitoring of the rational use of medicine (RUM) at the primary health center (PHC) showed the average use of antibiotics for non-pneumonia URTI in 2015 was $66.24 \%$ and in 2016 was $72.71 \%$. These results indicate that the use of antibiotics is still high, above the established indicator of $20 \%$ of antibiotics for non-pneumonia URTI. The report also mentioned several challenges faced in implementation of RUM, among others lack of training and technical guidance to health workers at health centers in the absence of specific policies and strict sanctions on the use of antibiotics rational. ${ }^{11}$

The Ministry of Health Republic of Indonesia has developed strategies and interventions including a rational drug use course, an essential medicine list, Module for Rational Use of Medicine, Clinical Practice Guideline for Physician in Primary Health Center, and Standard for Pharmacy Services at Primary Health Center. The guidelines contain systematically developed statements that include recommendations and information to assist physicians and other health care practitioners in $\mathrm{PHC}$ to make decisions about appropriate health care for the patient., ${ }^{1,2,12,13}$

Bogor is a city bordering Jakarta, the capital of the Republic of Indonesia, with an area of $118.50 \mathrm{~km}^{2}$, a population of 1,064,687 and Bogor has 24 primary health centers (PHCs) and 32 primary health sub-centers. ${ }^{14}$ Bogor City Health Profile 2015 stated that group of URTI for age between 5-44 years is the highest percentage of disease, consist of non-specific acute respiratory infection of $22.78 \%$, common cold $12.12 \%$, acute pharyngitis $4.56 \%$, acute tonsillitis of $2.52 \%$, while the lowest disease is acute laryngitis of $1.85 \%$. Total of acute URTI in Bogor city on 2015 reached $45.64 \%$. A large number of nonpneumonia acute respiratory cases occurring in Bogor city shows that non-pneumonia URTI is a public health problem. ${ }^{15}$

The rationality of the prescriptions in dose accuracy, choice of drug, and frequency and duration of administration are unknown. However, research evaluating the factors that influence the use of antibiotics by health providers in low-income countries is still rare. In the absence of research on prescribing antibiotics in primary health centers for URTI patients in Bogor city, it was necessary to conduct a study to evaluate whether antibiotics were prescribed rationally and research aimed to analyze the rationality of antibiotic prescriptions, analyzing factors influencing rationality, and management of rational use of medicine program.

\section{Methods}

This study is descriptive analytic research using cross-sectional research design with a quantitative approach, that is by doing the measurement of the medical record and qualitative data with observation and in-depth interview at the same time.

Outpatient medical record data of nonpneumonia URTI patient was taken prospectively 
in 16 April to 20 May 2018 at primary health centers in Bogor city. Medical record data is used to analyze the rationality of antibiotics used for the patients. The data used in this study are (a) Patient data: gender and age; (b) Diagnosis: non-pneumonia URTI, non-specific URTI, common cold, cough, nasopharyngitis, sinusitis, and pharyngitis; and (c) Treatment given: the number of items/types of drugs given in each prescription, type of antibiotics, doses of antibiotics, frequency/interval of consumption per day, and duration of antibiotics (in days).

Direct observation was conducted to get the description of physician service process which made the diagnosis as supporting data of rationality evaluation of antibiotics. These observations were carried out on three physicians who provided services at the outpatient clinic.

Observation is not only conducted for nonpneumonia URTI, but also to other diseases so that researchers have a complete description of the service process. Observation variables in this study were medical history interview, physical examination, information and education for patients about the disease and its treatment, completeness of the medical record. Observations were carried out for ten working days for 150 patients at the outpatient clinic.

In-depth interviews were conducted with informants to obtain confirmation about the results of the medical record review. Furthermore, conducted interviews with some informants selected purposely (purposive sampling) according to the needs of this study. The informants were three physicians to obtain factors influencing rationality of antibiotics; two pharmacists to get information implementation of monitoring use of medicine; and head of primary health center and two stakeholders at the health district office to obtain information about policy, implementation, and program management of rational use of medicine.

The study already had ethical approval from the Research and Community Health Services Ethics Committee of Faculty of Public Health Universitas Indonesia with letter-number: 200/ UN2.F10/PPM.00.02/2018.

\section{Results}

Medical record data in primer health centers at Bogor city during 16-30 April 2018 were 359 patients of non-pneumonia URTI. One hundred twenty-two (34\%) non-pneumonia URTI patients had antibiotics treatment and 102 patient data were used to analyze the rationality of nonpneumonia URTI antibiotic treatments.

The rationality of antibiotics obtained through the assessment of the accuracy of antibiotics selection, the accuracy of dosage, the accuracy of frequency, and antibiotics duration compared to the Clinical Practice Guidelines for Physicians in Primary Health Center from Ministry of Health Republic of Indonesia.

Acute nasopharyngitis is the most amount of non-pneumonia URTI reaching 226 patients (62.9\%) and the second is acute pharyngitis of 110 patients (30.6\%). Other non-pneumonia URTIs are acute tonsillitis 5.3\%, acute sinusitis and acute otitis media of $0.6 \%$ each.

The average number of drugs per prescription was 3.5 in the overall situation. Analgesics were the most commonly prescribed drug followed by antibiotics and antihistaminics. Amoxicillin

Table Evaluation of Rationality of Antibiotic Prescription for Non-pneumonia Upper Respiratory Tract Infection Patients

\begin{tabular}{|c|c|c|c|c|c|c|c|c|}
\hline \multirow{3}{*}{ URTI } & \multicolumn{8}{|c|}{ Rationality $(n=102)$} \\
\hline & \multicolumn{2}{|c|}{ Clinical Guideline } & \multicolumn{2}{|c|}{ Doses } & \multicolumn{2}{|c|}{ Frequency/ Interval } & \multicolumn{2}{|c|}{ Duration } \\
\hline & Conform & Unconform & Accurate & Inaccurate & Accurate & Inaccurate & Accurate & Inaccurate \\
\hline $\begin{array}{l}\text { Acute } \\
\text { nasopharyngitis, } \\
\text { acute rhinitis, } \\
\text { common cold }\end{array}$ & 8 & 5 & 13 & - & 13 & - & 2 & 11 \\
\hline Acute pharyngitis & 64 & 7 & 71 & - & 71 & - & 8 & 63 \\
\hline Acute tonsillitis & 16 & - & 15 & 1 & 16 & - & 1 & 15 \\
\hline Acute otitis media & 2 & - & 2 & - & 2 & - & 1 & 1 \\
\hline Total (\%) & $90(88)$ & $12(12)$ & 101 (99) & $1(1)$ & $102(100)$ & - & $12(12)$ & $90(88)$ \\
\hline
\end{tabular}


is the most widely used antibiotic in patients with non-pneumonia URTI, reaching 85.3\%. Other antibiotics used for the treatment of nonpneumonia URTI include cefadroxil 12.3\%, ciprofloxacin $0.16 \%$, and thiamphenicol $0.8 \%$.

Out of 122 patients with antibiotic treatments, 102 patients were fit to inclusion criteria and evaluated for the rationality of antibiotic use. The study revealed 99 (97\%) of the 102 patient prescriptions were not according to the clinical guideline and 3 (3\%) unconformity of guidance and inaccuracy of duration. The Table showed that $12(12 \%)$ of the prescriptions was unconformity with guidance, 90 (88\%) inaccuracy of duration, and 1 (1\%) inaccurate of dose.

The process of diagnosis performed by the physicians appropriates with the stages in the treatment guidelines. Examination of vital and physical signs was performed in a limited time so that most physicians didn't give information about disease and treatment. Information on patient treatment will give when the physician needs to emphasize patients on specific medications. Most medical records in information system were not written completely. The average medical consultation time for every patient at the primer health center was 2.3 minutes.

\section{Discussion}

The Ministry of Health of the Republic of Indonesia assigned 2.6 as an indicator of the average number of drug per patient. The medication level for each patient is quite high compared to other countries such as Cambodia 2.35, Saudi Arabia 2.4, Sudan 2.5, and India 2.8. ${ }^{16-19}$ However, compared to the WHO standard that suggested the average number of prescribed medications per patient was $1.6,{ }^{20}$ the above results indicated the presence of polypharmacy.

Polypharmacy is a large number of drugs in a prescription (with or without a prescription) for inappropriate clinical effects. ${ }^{1}$ The factors that cause polypharmacy are the physician's focus on providing therapy for symptoms, not disease diagnoses. ${ }^{19,20}$

The issue of excessive drug administration in non-pneumonia URTI patients is a common problem in Indonesia; some studies suggest that the amount of drug administered tends to be excessive especially antibiotics and steroid drugs. The economic impacts of polypharmacy are not directly felt by patients at PHC, as patients only pay 3,000 Indonesian rupiahs (IDR) for all medical services including medication. The increasing number of polypharmacy leads to an increase in the number of drugs to be provided at PHC. Finally, this has an impact on increasing costs for drug procurement. Increased drug procurement costs using national/district budgets indirectly increase the economic burden of the community through increased tax revenue target of the government.

Excessive drug use can stimulate patient demand for multiple drugs. If the patient is accustomed to getting large of drugs, they will tend to choose a physician who will prescribe that. Patients will have a belief that there is a cure for all diseases so they will demand different drugs for the various symptoms they complain.

The proportion of antibiotics of nonpneumonia URTI patients were $34 \%$. This proportion is lower than the national average in 2016 of $72.71 \%$ but has not reached the national indicator set at $20 \% .^{11}$

The results of research conducted by Hermawan and Kartika Sari ${ }^{21}$ showed that antibiotics in URTI patients reached $93.8 \%$ in Sukasada II Primary Health Center of Buleleng regency. Meanwhile, the various studies showed that non-pneumonia URTI generally caused by a virus and can be self-healed so that the use of antibiotics is not needed.

Amoxicillin is the most antibiotic administered to non-pneumonia URTI patients. This finding is consistent with the study that conducted in PHC at Depok city which stated that amoxicillin mostly used for acute pharyngitis (46.6\%) and non-specific (26.9\%); erythromycin for bronchopneumonia, acute pharyngitis, and acute tonsillitis (33.3\%); and cotrimoxazole for nonspecific (30.7\%) and acute pharyngitis (24.8\%). ${ }^{22}$

The physicians of PHC stated that amoxicillin administration was in accordance by the standard operating procesude (SOP) established by the $\mathrm{PHC}$, while the alternative antibiotics chosen by physicians was cotrimoxazole. However, in this analysis, the study was not found administration of cotrimoxazole and erythromycin recommended in treatment guidelines.

The other study had shown that high antibiotic use associated with increased bacterial resistance to antibiotics. A study in Health Service Unit of Universitas Jember by taking laboratory samples of URTI patients showed significant differences between amoxicillin and erythromycin. Eighty- 
five percent of bacteria are resistant to amoxicillin and $40 \%$ against erythromycin. Logarithmic regression result obtained minimum inhibitory level (MIL) amoxicillin was 7.48-9.02 mg/L and erythromycin $0.23-4.95 \mathrm{mg} / \mathrm{L}$. So it can be concluded that was a significant difference between the two drugs. The bacteria that cause secondary infection is no longer sensitive to amoxicillin. ${ }^{23}$

Rational use of the drug according to the WHO is if the patient received a drug that suits his needs to an adequate period at an affordable price for him and the community. The irrational use of drugs is an important issue that can have a substantial impact on the deterioration of the quality of health services which can result in increased resistance to the use of irrational antibiotics. Use of the drug said not rational if cannot be accounted medically (medically inappropriate) both regarding the accuracy of the type, the dosage, and how to administer the drug.,2

The findings of 99 (97\%) of the 102 patient prescriptions not in accordance to the clinical guideline, largely due to the duration of drug administration that was inconsistent with the guidelines even most antibiotics were given for only 3 days of treatment. In addition to the duration, the irrationality of antibiotics due to the selection of antibiotics and inappropriate dosage. Selection of cefadroxil which is cephalosporin group are second-line antibiotics for URTI and are used when there is suspicion of resistance. Muhlis's ${ }^{24}$ study in one of PHC at Yogyakarta resulted not much different, all prescriptions met the accuracy of dosage and frequency, except cotrimoxazole dose $98 \%$ and ampicillin dose 49\%. All prescriptions (100\%) did not meet the exact duration of antibiotic use. The duration of administration of antibiotics according to the Regulation of Ministry of Health of the Republic of Indonesia is given for 6-10 days. ${ }^{25}$

The process of diagnosis is an important factor in RUM, the accuracy of disease diagnosis will determine the treatment that will be given by the physicians so that this study carried out the observation of the diagnosis enforcement process according to the Indonesian Good Medical Practice. ${ }^{26}$

The average length of medical consultation at PHC is 2.3 minutes. The medical consultation time is the time provided by the family physician to the patient is sufficient for the patient to express his or her complaint and wishes, sufficient for the physician to explain what he has gained in the history and physical examination, and enough to foster the patient's participation in carrying out the management he or she chooses as long as 10 minutes for each patient. ${ }^{27}$ The research at $3 \mathrm{PHC}$ in Cambodia resulted in medical consultation time of 4.43 minutes. This time is still far from Cambodia's national standard $>10$ minutes. ${ }^{16}$

Physicians of PHC explain that they have very high outpatients visit reached 150-200 patient visits, while PHC only has 3 doctors or sometimes only 2 doctors serve all patients without any assistance to call out the patient or measure the blood patients. And outpatient services have to be finished at 1 or 2 o'clock, so if the doctors did not work fast, not all the patient would get the outpatient services.

The researcher saw that the whole process of diagnosis by physicians in accordance with the stages in the guidelines, starting from probe the history of the diseases, physical examination and additional examination or appropriate action and refer the patient if necessary, but short medical consultation time causes inadequate information about the illness and treatment given to the patient. Patients have few opportunities to obtain information about their care.

\section{Conclusions}

Some factors that influencing rationality of antibiotics prescription were lack of physian's adherence to clinical guideline, pharmacist role for the rational use of medicine program were not optimal, and lack of monitoring evaluating for the rational use of medicine program.

\section{Conflict of Interest}

The authors declare no conflict of interests.

\section{Acknowledgement}

Thank you to the puskesmas doctors, nurses, administrative staff, and patients for good supports and collaboration in this study.

\section{References}

1. Direktorat Jenderal Bina Kefarmasian dan Alat Kesehatan, Kementerian Kesehatan Republik Indonesia. Modul penggunaan obat 
rasional. Jakarta: Kementerian Kesehatan Republik Indonesia; 2011.

2. Direktorat Bina Obat Publik dan dan Perbekalan Kesehatan, Direktorat Jenderal Bina Kefarmasian dan Alat Kesehatan, Kementerian Kesehatan Republik Indonesia. Materi pelatihan manajemen kefarmasian di puskesmas. Jakarta: Kementerian Kesehatan Republik Indonesia; 2010.

3. World Health Organization (WHO). The pursuit of responsible use of medicines: sharing and learning from country experiences. Geneva: WHO Press; 2012.

4. Badan Penelitian dan Pengembangan Kesehatan, Kementerian Kesehatan Republik Indonesia. Riset kesehatan dasar (Riskesdas) 2013. Jakarta: Kementerian Kesehatan Republik Indonesia; 2013.

5. World Health Organization (WHO). WHO global principles for the containment of antimicrobial resistance in animal intended for food. Geneva: WHO; 2000.

6. World Health Organization (WHO), International statistical classification of diseases and related health problems $10^{\text {th }}$ revision. ICD-10 Version: 2016 [cited 2018 April 25]. Available from: https://icd.who. int/browse10/2016/en.

7. Mohrs S. Factors influencing the use of antibiotics and knowledge about antibiotic resistance in Jakarta. A qualitative study on the perceptions of stakeholders involved in Yayasan Orangtua Peduli's Smart Use of Antibiotics campaign in Indonesia. 27 May 2015 [cited 2018 April 25]. Available from: https://uu.diva-portal.org/smash/get/ diva2:971676/FULLTEXTo1.pdf.

8. Lee TH, Wong JGX, Lye DCB, Chen MIC, Loh VWK, Leo YS, et al. Medical and psychosocial factors associated with antibiotic prescribing in primary care: survey questionnaire and factor analysis. $\mathrm{Br} \mathrm{J}$ Gen Pract. 2017;67(656): e168-77.

9. Jaruseviciene L, Radzeviciene Jurgute R, Bjerrum L, Jurgutis A, Jarusevicius G, Lazarus JV. Enabling factors for antibiotic prescribing for upper respiratory tract infections: perspectives of Lithuanian and Russian general practitioners. Ups J Med Sci. 2013;118(2):98-104.

10. Kotwani A, Wattal C, Katewa S, Joshi PC, Holloway K. Factors influencing primary care physicians to prescribe antibiotics in Delhi
India. Fam Pract. 2010;27(6):684-90.

11. Direktorat Jenderal Kefarmasian dan Alat Kesehatan, Kementerian Kesehatan Republik Indonesia. Laporan akuntabilitas kinerja Direktorat Pelayanan Kefarmasian tahun 2016. Jakarta: Kementerian Kesehatan Republik Indonesia; 2017.

12. Keputusan Menteri Kesehatan Republik Indonesia Nomor HK.02.02/ MENKES/514/2015 tentang Panduan Praktik Klinis Bagi Dokter di Fasilitas Pelayanan Kesehatan Tingkat Pertama.

13. Peraturan Menteri Kesehatan Republik Indonesia Nomor 74 Tahun 2016 tentang Standar Pelayanan Kefarmasian di Puskesmas.

14. Badan Pusat Statistik Kota Bogor. Kota Bogor dalam angka 2017. Bogor: Badan Pusat Statistik Kota Bogor; 2017.

15. Dinas Kesehatan Kota Bogor. Profil kesehatan Kota Bogor tahun 2015. Bogor: Dinas Kesehatan Kota Bogor; 2015.

16. Chareonkul C, Khun VL, Boonshuyar C. Rational drug use in Cambodia: study of three pilot health centers in Kampong Thom province. Southeast Asian J Trop Med Public Health. 2002;33(2):418-24.

17. El Mahalli AA. WHO/INRUD drug prescribing indicators at primary health care centres in Eastern province, Saudi Arabia. East Mediterr Health J. 2012;18(11):1091-6.

18. Supakankunti S, Yousif BME. Factors influencing the general practitioners' number of prescribed drugs in National Health Insurance at Gezira state, Sudan. Int J Bus Soc Sci. 2016;7(1):213-9.

19. Bhartiy SS, Shinde M, Nandeshwar S, Tiwari SC. Pattern of prescribing practices in the Madhya Pradesh, India. Kathmandu Univ Med J. 2008;6(1):55-9.

20. Kardela W, Andrajati R, Supardi S. Perbandingan penggunaan obat rasional berdasarkan indikator WHO di puskesmas kecamatan antara Kota Depok dan Jakarta Selatan. JKI. 2014;4(2):91-102.

21. Hermawan, Kartika Sari KA. Pola pemberian antibiotik pada pasien ISPA bagian atas di Puskesmas Sukasada II pada bulan Mei-Juni 2014. E-Jurnal Medika Udayana. 2014;3(10). [cited 2018 April 25]. Available from: https:// ojs.unud.ac.id/index.php/eum/article/ view/11935.

22. Tilaqza A. Pola peresepan antibiotik dan 
Wiwi Ambarwati et al.: Antibiotics Used for Upper Respiratory Tract Infection: a Case Study at the Primary Health Center

faktor-faktor yang berhubungan dengan kerasionalan peresepan antibiotik di Puskesmas Kecamatan Kota Depok tahun 2012. [cited 2018 April 25]. Available from: http://lib.ui.ac.id/file?file=digital/201610/20350387-T38415-Andri\%20Tilaqza.pdf.

23. Putri OYK, Abrori C, Wiji Astuti IS. Uji sensitivitas amoksisilin dan eritromisin terhadap infeksi sekunder dari spesimen pasien infeksi saluran pernafasan akut. JPK. 2015;3(1):18-23.

24. Muhlis M. Kajian peresepan antibiotika pada pasien dewasa di salah satu puskesmas Kota Yogyakarta periode Januari-April 2010.
Pharmaciana. 2011;1(1):33-41.

25. Peraturan Menteri Kesehatan Republik Indonesia Nomor 5 Tahun 2014 tentang Panduan Praktis Klinis Bagi Dokter di Fasilitas Pelayanan Kesehatan Primer.

26. Konsil Kedokteran Indonesia (KKI). Penyelenggaraan praktik kedokteran yang baik di Indonesia. Jakarta: Konsil Kedokteran Indonesia; 2006.

27. Perhimpunan Dokter Keluarga Indonesia (PDKI). Standar pelayanan dokter keluarga. Jakarta: Perhimpunan Dokter Keluarga Indonesia; 2006. 